\title{
Some Effects of Sound and Music on Organisms and Cells: A Review
}

\author{
Jean-Marie Exbrayat ${ }^{{ }^{*}}$ and Claire Brun ${ }^{1}$ \\ ${ }^{1}$ UMRS 449 "General Biology - Reproduction and Comparative Development", Lyon Catholic \\ University (UCLy, UDL), Ecole Pratique des Hautes Etudes (EPHE, PSL), 10 Place des Archives,
} 69288 Lyon Cedex 02, France.

Authors' contributions

This work was carried out in collaboration between both authors. Authors CB and JME participated in an equal work in realizing the review. Author JME wrote the draft of article and author CB corrected it. Authors CB and JME wrote the definitive manuscript. Both authors read and approved the final manuscript.

Article Information

DOI: $10.9734 / A R R B / 2019 / v 32 i 230080$

Editor(s):

(1) Dr. Xiao-Xin Yan, Professor, Department of Anatomy and Neurobiology, Central South University Xiangya School of Medicine (CSU-XYSM), China.

(2) Dr. George Perry, Dean and Professor of Biology, University of Texas at San Antonio, USA. Reviewers:

(1) Elias Ernesto Aguirre Siancas, Universidad Nacional Mayor de San Marcos, Perú. (2) Izdebska Magdalena, Copernicus University, Poland. (3) Vaishali Waindeskar, All India Institutes of Medical Sciences, India. Complete Peer review History: http://www.sdiarticle3.com/review-history/49598

Review Article

Received 06 April 2019

Accepted 22 June 2019

Published 28 June 2019

\section{ABSTRACT}

In animals, the sound vibrations are captured by the auditory cells, then transformed into electrical signals and conveyed to the nervous centers where they can be interpreted such as music. A lot of studies concern the effect of sound on the auditory cells and on the brain. Nevertheless, musical vibrations also affect other cells types in several organisms. These researches being not of the same nature, they need to be classified in order to provide elements of understanding the effects of music on cell biology. A lot of works were done on the effects of music on non-auditory cells. Effects on growth, apoptosis, immune system, protein activities in animal, plant and bacterial cells have been shown. These effects are of a physiological nature and require molecules and physicochemical mechanisms. Some works were performed on vegetal or animal total organisms, others directly on cells themselves, using cell cultures. Few works concern eukaryotic unicellular organisms. Results of these studies show music and sound exert effects on the physiology. But the 
experiments and results are still well disparate, with effects of different types of music on organisms via auditory on non-auditory cells, sometimes involving both auditory and non-auditory cells. Whatever the large variation of results, the study of the effects of sound and especially music on the cells is a subject on the future, considering the immense possibilities offered by music in modulating physiology, with potential therapeutic applications.

Keywords: Sound; music; auditory cell; non-auditory cell; plant; animal; unicellular organism.

\section{INTRODUCTION}

The music is an organized sequence of sounds. In animals, the sound vibrations are captured by the auditory cells where they are transformed into electrical signals, themselves conveyed to the higher nervous centers [1]. At this level, the information is interpreted and reconstructed to give music with a particular emotional connotation [2-4]. Since several years, the effects of music have been studied on several disparate ways, from the decrease of stress in different kinds of patients to the effects on several biochemical factors. For example, music reduced anxiety in women undergoing colposcopy. The authors of the study concluded it was possible the experiment increased the knowledge levels, and the clinical consent to the colposcopy was more easily obtained [5]. In a totally different register, the effects of music are beneficial on emotions, stress, and also immune system. Biochemical molecules such as neurotransmitters, hormones, cytokines, and peptides act such as intermediary between music and its effects [6].

Among the studies, a lot of them concern the effect of sound wavelengths on the auditory cells. Nevertheless, musical vibrations also affect other cells types, and not only on animal organisms. Since several years, researchers have studied the effects of music on different aspects of physiology in several kinds of organisms. This review aims to take a quick look at these works, which are still disparate, and to classify these researches being not of the same nature, to provide elements of understanding the effects of music on cell biology. Firstly, the main effects of sound and more especially music in plants and unicellular prokaryotic and eukaryotic organisms will be described. Then, the effects of music will be examined successively on different aspects of animal biology on the total organism, and also on isolated cells and cell cultures. Some aspects of harmful effects of noise on organisms will be also given.

\section{THE EFFECTS OF SOUND AND MUSIC UPON NON-ANIMAL ORGANISMS}

\subsection{On Plants}

Plant cells respond to sound waves. These can influence germination rates and increase plant growth and development, improving the yield of some crops $[7,8]$. In addition, it is currently accepted that sound waves can enhance the plant immunity against pathogens [9] and may also increase their tolerance to drought [10]. More surprisingly, plants can recognize the mating sounds of insect larvae and the buzz of a pollinating bee and respond accordingly [11]. Thus, evidence of acoustic communication during plant-animal interactions seems to be confirmed [12]. For example, some batdependent plants have adapted to their echolocation systems by providing acoustic reflectors to attract their animal partners [8].

At the cellular level, sound vibrations can affect microfilament rearrangements, increase levels of soluble polyamines and sugars, modify the activity of various proteins, and regulate the transcription of certain genes $[7,13,14]$. In Chinese cabbage and cucumber exposed to ultrasound, to classical music or loud sounds, the level of polyamines and the following oxygen uptake increased significantly [13]. The increases observed are greater in the plants exposed to musical sounds. On the other hand, the authors did not observe a variation of the vitamin $C$ level. The effects of the sound are complex, and influence the physiological mechanisms. In particular, acoustic stress as environmental stress induces a downregulation of the expression of certain genes [14].

\subsection{Effects on Unicellular Organisms}

Unicellular cells, eukaryotic or prokaryotic, are sensitive to the effects of music which can affect survival and activity of microorganisms [15]. In Escherichia coli, audible sound increases the colony forming under the normal condition, and 
enhance the inhibitory effect of osmotic stress [16]. Indian music with sounds between 38 and $689 \mathrm{~Hz}$ had a positive effect on the growth of bacteria and yeasts (with an increase of 3.15 to $40.37 \%$ ), except for the species Serratia marcescens. Music also influences the production of metabolites, antibiotic sensitivity. The bacterium Chromobacterium violaceum and the yeast $S$. marcescens break down more quickly cephazoline, an antibacterial agent. In organisms subject to musical vibrations, membrane permeability seems to be impaired; the intracellular concentration of calcium and potassium and the protein content are also significantly different from those of the control. The "audible sound in the form of music" like said the authors, has thus been able to affect the growth, metabolism and antibiotic sensitivity of bacteria (prokaryotes) and yeast (eukaryotes) [17]. In Staphylococcus aureus, low-intensity pulsed waves decreased the number of bacteria colonies compared to bacteria which were not submitted to sound. The cell membranes of the tested bacteria were partially broken and the thickness of bacterial cell wall was higher in the bacteria submitted to sound $(41.54 \mathrm{~nm}$ instead $24.27 \mathrm{~nm}$ ) [18]. Experiments in several bacteria, and particularly Bacillus subtilis and $B$. carboniphilus suggested sound communication between bacteria $[19,20]$.

\section{THE EFFECTS ON ANIMALS}

\subsection{Reception of Sounds by Auditory Cells}

Hearing cells, still called hair cells, are sensory cells emitting stereocilia. These cells are arranged along the basilar membrane lining the inside of the cochlea, the spiral hearing organ. The outer cylindrical cells contract periodically by amplifying the sound signal, and the inner pearshaped hair cells transform the amplified signal into an electrical signal $[21,22]$. The cells situated at the beginning of the cochlea receive the highest frequencies; those at the end of the spiral receive the lowest ones. The deflection of stereocilia causes the opening of ion channels, causing the entry of $\mathrm{K}^{+}$ions which depolarize the cell and create an electrical receptor potential. Calcium channels are opened depending on the potential of the receptor and $\mathrm{Ca}^{++}$enter the cell, releasing glutamate, a neurotransmitter, at the base of the cell at the level of synaptic ribbons, related to the axons of neurons. Glutamate binds to afferent nerve fiber receptors and triggers action potentials in the nerve. To resume, the inner hair cells are set in motion by a sound wave that triggers the release of neurotransmitters, creating a signal that is transmitted to the auditory areas of the brain [23-26].

Non-auditory cells can also respond to sound. The fluids contained by all the cells are thus sensitive to the variations of pressure induced by the sound waves and no cell type can theoretically hinder a pure sound or music. Several studies show that the mechanisms of growth arrest and cell death induced by acoustic vibrations are similar for auditory and nonauditory cells $[27,28]$.

\subsection{Some Effects on the Whole Organisms}

\subsubsection{Effects on stress}

The effects of music on stress have been well investigated, and several reviews were published $[29,30]$. These studies are managed in different manners that can be illustrated with two examples, one concerning human beings, the other concerning animals.

Listening to music is used since a long time in order to induce relaxation. The mechanisms of these beneficial effects have been studied in persons listening music. After listening music, the number of blood mononuclear cells and morphine 6 glucuronide increased; IL-6 levels decreased significantly, IL-1b, IL-10 and cortisol did not vary. In people having listen music, the signal molecule changed in plasma, and was accompanied with some physiological changes [31].

The effects of auditory and physical enrichment have been studied in chicks. For auditory enrichment, the chicks have been submitted to classical music. For physical enrichment, others chicks have been bred in front of hanging colored string bunches and with barley grains on the floor. Music reduced the stress characterized by the measure of different parameters (duration of tonic immobility, white blood cells of birds / lymphocyte ratio, and fluctuating asymmetry). The results suggested that auditory enrichment from classical music reduced stress in chicks. At contrary, no significant results were obtained with physical enrichment [32]. 


\subsubsection{Some effects on embryonic development}

The fluctuating asymmetry of an organism is a small random deviation from a perfect bilateral symmetry that results from genetic and / or environmental stress during development [33]. During growth, morphological differences were found in chicks reared without music compared to chicks with a musical environment: asymmetry of wing length, leg thickness and greater combined asymmetry. Like see above, the auditory enrichment decreased the fluctuating asymmetry in chicks [32].

Several studies have shown some effects of music on the embryonic development of brain. Music facilitates the neurogenesis, regeneration and repair of neurons in humans [34]. In rats, the exposure to music during pregnancy increased the neurogenesis in the hippocampus and enhanced spatial learning ability. But inversely, the exposure to noise (which can be defined such as an unorganized sequence of frequencies) during pregnancy decreased neurogenesis in the hippocampus, with growth retardation, and impaired spatial learning ability [35].

In brain of music-overstimulated developing chicks, an increase of auditory nuclei was observed consequently to the increase in number and size of neurons. In animals submitted to attenuated sound, the number of cell nuclei of large size slightly increased, and the number of glial cells also increased. The dissociated responses of neurons and glial cells suggested these two kinds of cells were independently regulated [36]. Prenatal auditory enrichment of chicks with species-specific sounds or with other music modulates the expression of $\mathrm{Bcl}-2$ and Bax and consequently the programmed cell death [37]. Apoptosis is indeed a fundamental phenomenon in shaping the future nervous system in vertebrates [38]. Postnatal auditory stimulation influences early perceptual learning. The effects of several kinds of sound, music (KV 448, Mozart), and silence was studied on adult neurogenesis in mouse. After $24 \mathrm{~h}$ of exposition to all these stimuli, including silence, the proliferation of precursor cells labeled with BrdU increased. But after 7 days of exposure, only silence increased the number of labeled neurons [39].

In chicks, some works showed that prenatal auditory stimulation was associated with morphological and biochemical variations in the hippocampus and brainstem auditory nuclei. Consequences were observed upon the ability for spatial orientation and learning of chicks. High decibel $(110 \mathrm{~dB})$ music stimulation increased moderately noradrenaline level in plasma and consequently positively modulated spatial orientation, learning and memory in one-day-old chicks. Noise increased plasma noradrenaline level and impaired the spatial behavior. In musicstimulated chicks, two markers of synaptogenesis, synaptophysin and PSD-95, significantly increased [40]. In animals stimulated by music, increase of neuron number and neuronal nuclear area was observed using histology and image analysis [41]. A reduction of total neuron number was found in chicks submitted to an unorganized noise. The neuronal nuclear area increased in the field $L$ but decreased in the auditory nuclei and hippocampus. Glial cell number significantly increased in chicks submitted to music or noise, with the highest value in the noise group. So, the effects of sounds are related to its characteristics (music or noise) [41].

Always in chicks, the development of forebrain areas involved in juvenile auditory filial-imprinting was studied in animals auditory-stimulated by sitar music $10 \mathrm{pf}$ days till hatching. In the stimulated groups, nuclear areas significantly increased compared to controls, with difference between music stimulated animals compared to animals submitted to species-specific sounds. In animals submitted to species-specific sounds, cells immunostained with anti-parvalbumin (PV) and anti-calbindin D28K (CaBP), a calciumbinding protein, increased compared to musicstimulated animals. This increase of neurons is certainly linked to auditory imprinting and learning in chick [42].

Music would also improve the success of in vitro fertilization [43].

\subsubsection{Effects of sound and music on the immune system}

The effects of music therapy were investigated in patients with stroke, Alzheimer's disease or Parkinson's disease [44]. At the end of the treatment, the percentage and activity of the Natural Killer cells (NK) of the immune system increased independently of the pathological state. Similarly, rhythmic percussion was causing an increase in natural NK and activating the ratio of dehydroepiandrosterone (DHA) / cortisol, 
acting on aging. There is no action detected on other parameters. These effects are different from the effects of a simple noise [45]. In individuals submitted to a stressful activity, music increased the feeling of wellbeing. So, a very lively music caused the increase of norepinephrine level, vitality and decreased the characteristics of depression. Active NK cells decreased after 20 minutes of silence. The results of the study showed that different kinds of music and sounds had different effects on immune, neuroendocrine, and psychological responses [46]. In another study, the effects of a recreational music-making were evaluated on male corporate employees. By comparison with controls, the group of persons listening music showed enhanced mood, lower gene expression levels of the stress-induced cytokine interleukin10 , and higher NK cell activity when compared to the control [47].

The effects of gong sound on immune function were studied in rats with Chinese diet-induced Liver (Gan) -Si Stagnation and Spleen-qi Seficiency syndrome (LSSD). The animals were divided into five groups: 1) normal; 2) "LSSD group": rats with induced LSSD rats; 3 ) "Xiaoyao Powder group": rats with LSSD having received a traditional Chinese mixture of medicinal plants, the Xiaoyao Powder; 4) " Gong-tone group": rats with LSSD subjected to gong sound and 5) "Combined group": rats with LSSD both subjected to gong sound and receiving "Xiaoyao powder". Serum gastrin, phagocytosis by macrophage IgG levels and $T$ cell proliferation decreased in the LSSD group compared to the normal group. The same parameters increased in the "Gong-tone", "Xiaoyao Powder" and "combined" groups, the parameters of the combined group being higher than those of the other two groups [48]. In young rats and adults who became asthmatic after provoking stress, the number of white blood cells and IL-4 increased. Corticosteronemia increased in the stressed adult group, while corticosterone IL-1 $\beta$ increased in stressed youth and then decreased in adults. In young and adult animals, the stress response of the hypothalamic-pituitary-adrenal (HPA) axis was also different. Corticosteronemia and IL-4 were reduced in rats that heard music (Mozart's Sonata K.448) [49]. The effects of music on the immune system were also studied in mouse. The animals were subjected to either noise (wide band of sound) from midnight and / or to music for 5 hours the following morning. Cellularity of the thymus and spleen (cell density), $\mathrm{T}$ cell population, splenocyte proliferative response to mitogens (concavalin A), and $\mathrm{K}$ cell activity were improved in BALB / c mice subjected to music [50].

The music thus has effects on the immune, endocrine and psychological responses. The music modulates particularly the activity of the NK cells, the cytokines. There are also subtle variations depending on the type of music (lively, slow, percussion, etc.).

A few papers enlightened by Liao [51] described the effects of music on the allograft survival. The effects of music on allograft survival and the establishment of regulatory $\mathrm{CD}^{+}$cells were also studied in an experimental mouse murine transplant model $[52,53]$ Mice rendered deaf (CBA / N strain) underwent transplantation of a heart from another strain (C57BL / 6). The mice were exposed for 7 days to three types of music: an opera (La Traviata, Verdi), a classical instrumental music (Mozart) and New Age music. A control group was exposed to one of six different sound frequencies. Allograft survival was significantly prolonged in animals exposed to opera and classical music; the survival of grafts of animals exposed to unique sound frequencies and New Age music was more limited. Modulations were observed depending on the type of music. Cellular proliferation, IL-2 and IF- $y$ were suppressed in operably exposed mice, while IL-4 and IL-10 were upregulated and the cell population $\mathrm{CD}^{+}, \mathrm{CD}^{2} 5^{+}, \mathrm{Foxp}^{+}$ regulators increased. Exposure to certain types of music can induce a prolonged survival of cardiac allografts and generate regulatory cells.

\section{EFFECTS ON CELL-CULTURES OR ISOLATED CELLS}

\subsection{Effects on Red Blood Cells}

Classical music increases the deformability of red blood cells. A fine study has shown that classical music and rock reduced the aggregation of red blood cells, a little more important in the case of classical music [54]. This result shows that sound and more especially music exert effects on the surface properties of these cells. Inversely, the exposure to an unpleasant, unorganized noise has no particular effect. In human blood cells the activity of adenylate kinase, a membrane protein essential for the integration of external signals in cells, increases after exposure to a low frequency field (ELF) and decreases slightly after exposure to a 
TAMMEF field (music-modulated [55]). The low frequencies can thus have an influence on the cellular electrical charge and the stimulation of the adenylate kinase activity brings the cell to a state of equilibrium. The music acts by maintaining and regulating the cellular electric charge [55].

\subsection{Osteoarthrosis Cartilaginous Cells}

Human osteoarthritic chondrocytes grown in vitro under two- and three-dimensional conditions were exposed to electromagnetic fields at low frequencies (ELF; $100 \mathrm{~Hz}$, electromagnetic waves) or music-modulated electromagnetic fields (TAMMEF) [56,57]. The exposure of cells to both types of vibration improved cell proliferation, did not generate reactive oxygen species (ROS), did not cause the depletion of glutathione, did not modify the mitochondrial transmembrane potential and did not induce apoptosis. In addition, the cells exposed to TAMMEFs presented a better viability compared to the cells exposed to ELFs, with grouping and improvement of the density of healthy cells in cultures. Differences in protein expression showed improved stress response, cytoskeletal regulation, and inflammation. The electromagnetic waves modified with music (TAMMEF) could interfere positively with the chondrocytes: not only they did not damage them, but they stimulated their viability by modulating the expression of proteins, the production of ROS (reactive derivatives of the oxygen) and the apoptosis. The music could help to identify biomarkers and could allow a new approach to the treatment of osteoarthritis. But let's stay cautious.

In other experiments, in vitro osteoarthritic chondrocytes were cultivated in standard conditions or stimulated with IL-1 $\beta$ or IGF1 in order to become between chondro-formation and chondro-resorption in case of osteoarthritis. In cultures submitted to ELFs or TAMMEFs, the proliferation of cells was enhanced, apoptosis was not induced, ROS were not generated, there were no changes in mitochondrial transmembrane potential, no gluthatione depletion was observed [58].

\subsection{Tumor Cell Strain}

Other work has suggested that music can alter in vitro the size and granularity of MCF7 cells, a tumor cell strain derived from breast cancer, by interfering with the binding of hormones to their receptors, which modulate the physiological processes $[27,28]$. Music limits the development of pulmonary metastases caused by the injection of these tumor cells [50].

\section{THE HARMFUL EFFECTS OF NOISE}

The effects of music could be special cases of sound effects on cells. Works show that any type of sound can have or not beneficial effects. There are sounds with harmful effects, this is the case of noise, a set of unpleasant sounds in the ear and, as we will see, causes disturbances at the most unexpected cellular level. A review summarized the effects of different levels of noise resulting from certain leisure activities: exposure to very strong music, being rock, classical or jazz; exposures from personal listening devices; noise around houses, gunshots or target shooting. The greatest threat to hearing comes from these last sounds [59].

The effects of sound pulses were studied on epithelial cells of the choroidal plexus of rats. The animals were exposed to impulses every 20 minutes 10 times a day for one month. At the end of the experiment, the choroidal plexuses were removed and examined by histology. Compared to controls, the number of normal cells decreased and the number of apoptotic cells increased. The noisy impulses thus caused the apoptotic death of the choroidal plexus cells [60]. In another experiment, rats were exposed to rock music at 80 decibels for 24 hours, during which control animals were kept in their usual environment [61]. Leukocyte subpopulations were obtained and stimulated in vitro. Neutrophils and macrophages in noise-exposed animals secreted significantly less superoxide and interleukin-1 than control animals. The shortterm exposure of rats to noise modified some of the functions of leukocytes [61].

\section{DISCUSSION AND CONCLUSION}

Research on the effects of music on cells is an expanding field. It has long been known that music has beneficial effects to calm stress, anxiety, and even pain. Studies on the effects of sound vibrations on auditory cells have been conducted for a long time [62]. More recently, more and more works about the effects of music on non-auditory cells have been published. Thus, the effects on growth, apoptosis, action of proteins, immune system in animal, plant and bacterial cells could be demonstrated. These effects, which contribute to favoring positive 
emotions, are of a physiological nature and require molecules and physicochemical mechanisms. The molecules involved include neurotransmitters, hormones, cytokines and peptides.

The music affects the immune, endocrine and psychological responses. The music modulates in particular the activity of the NK cells and the cytokines. There are also subtle variations depending on the type of music (lively, slow, percussion, etc.). The effects of sound and more particularly music have been used for therapeutic purposes. The Mozart effect can be resumed based on these works. According to the 1993 publication of Rauscher et al. [63] the Mozart effect concerns the improvement of reasoning skills in normal subjects after listening to Mozart's K 448 piano sonata. In 2014, Pauwels et al. have taken up this effect by considering that music can modulate the immune response by increasing the activity of NK cells, lymphocytes and interferon-y [64]. Appreciated music would help to strengthen the immune system and to change stress, reducing it. Finally, the effect of music used to reduce stress, heart rate, blood pressure and to distract the patient could be related to the effects on the immune system [64].

Experiments have been performed in order to discover the effects of music on several aspects of biology and physiology, and several papers have been published about very different subjects. For example, in rat, $432 \mathrm{~Hz}$ and $440 \mathrm{~Hz}$ musical frequencies increased the expression of Ghrelin (Ghre), a peptide secreted from the stomach under fasting conditions, inducing food intake. This peptide stimulating appetite through neuropeptide $Y$, it seems that musical frequencies could affect food intake by modulating the hypothalamic Ghre expression and release [65]. In urethane-anesthetized rats, renal sympathic nerve activity (RSNA) on blood pressure decreased in subjects listening Traeumerei by Schumann. In anesthetized rats, such a musical stimulation caused an elevation of gastric vagal nerve activity and increased the c-Fos labeled cells of the auditory cortex $[66,67]$.

A compilation of published studies concerning numerous vertebrate species permitted to identify several candidate genes allowing one to give a molecular basis of musical traits [68]. Besides these studies, the importance of the effects of music has been understood since a long time. Several publications concern the effects of music therapy. Without being exhaustive, several recent works are related to the increasing of altruism through the regulation of steroid hormones by music [69]. Use of music gave positive results in the treatment of patients undergoing allogeneic hematopoietic stem cell transplantation, providing welfare of patients [70]; some experiments have been performed in animal in order to understand the mechanisms implicated [71].

Finally, a lot of current studies concern the effects of sound and more especially music upon the organisms. These studies belong to different domains of research. Some of them - the most numerous - are devoted to the effects on the brain through the auditory cells. Others concern the effects directly upon the non-auditory cells. Certain works were performed on vegetal or animal organisms, others directly on cells themselves, using cell cultures. Few works concern eukaryotic unicellular organisms. Results of these studies show music and sound exert true effects on the physiology. But the experiments and results are still well disparate, with effects on organisms via auditory cells, on non-auditory cells, sometimes involving both auditory and no auditory cells, and with the use of different music according to the culture of the country where the study has been done.

In conclusion, nevertheless this large variation of works or results, the study of the effects of sound and especially music on the cells is a subject on the future, considering the immense possibilities offered by music in modulating the physiology, with potential therapeutic application.

\section{ACKNOWLEDGEMENTS}

The authors thank Lyon Catholic University which supported this work.

\section{COMPETING INTERESTS}

Authors have declared that no competing interests exist.

\section{REFERENCES}

1. Fettiplace R. Hair cell transduction, tuning, and synaptic transmission in the Mammalian cochlea. Compr Physiol. 2017; 7(4):1197-1227.

Available:https://doi.org/10.1002/cphy.c160 049 
2. Blood AJ, Zatorre R. Intensely pleasurable responses to music correlate with activity in brain regions implicated in reward and emotion. PNAS. 2001;98:11818-11823.

3. Gosselin N, Samson S, Adolphs R, Noulhiane M, Roy M, Hasboun D, et al. Emotional responses to unpleasant music correlates with damage to the parahippocampal cortex. Brain. 2006;129: 2585-2592.

4. Khalfa S, Guye M, Peretz I, Chapon F, Girard N, Chauvel P, et al. Evidence of lateralized anteromedial temporal structures involvement in musical emotion processing. Neuropsychologia. 2008; 46(10):2485-2493.

Available:https://doi.org/10.1016/j.neurops ychologia.2008.04.009

5. Galaal KA, Deane K, Sangal S, Lopes AD. Interventions for reducing anxiety in women undergoing colposcopy. Cochrane Database Syst Rev. 2007;18(3): CD006013.

6. Gangrade A. The effect of music on the production of neurotransmitters, hormones, cytokines, and peptides: A review. Music and Medicine. 2012;4(1):40-43.

7. Mishra RC, Ghosh R, Bae H. Plant acoustics: in the search of a sound mechanism for sound signaling in plants. $J$ Exp Bot. 2016;67(15):4483-4494. Available:https://doi.org/10.1093/jxb/erw23 5

8. Vicient CM. The effect of frequencyspecific sound signals on the germination of maize seeds. BMC Research Notes. 2017; $10: 323$

Available:https://doi.org/10.1186/s13104017-2643-4

9. Choi B, Ghosh R, Gururani MA et al. Positive regulatory role of sound vibration treatment in Arabidopsis thaliana against Botrytis cinerea infection. Scientific Reports. 2017;7:2527.

10. Lopez-Ribera I, Vicient CM. Drought tolerance induced by sound in Arabidopsis plants. Plant Signal Behav. 2017;12(10): e1368938.

Available:https://doi.org/10.1080/15592324 .2017 .1368938

11. De Luca PA, Vallejo-Marin M. What's the 'buzz' about? The ecology and evolutionary significance of buzz pollination. Curr Opin Plant Biol. 2013; 16(4):429-435.
Available:https://doi.org/10.1016/j.pbi.2013 .05 .002

12. Schöner $M G$, Simon $R$, Schöner $C R$. Acoustic communication in plant-animal interactions. Curr Opin Plant Biol. 2016;32: 88-95.

Available:https://doi.org/10.1016/j.pbi.2016 .06 .011

13. Qin YC, Lee WC, Choi YC, Kim TW. Biochemical and physiological changes in plants as a result of different sonic exposures. Ultrasonics. 2003;41(5):407411.

14. Hongbo S, Biao L, Bochu W, Kun T, Yilong L. A study on differentially expressed gene screening of Chrysanthemum plants under sound stress. C R Biol. 2008;331(5):329333.

Available:https://doi.org/10.1016/j.crvi.2008 .02 .007

15. Mortazavian AM. Music affects survival and activity of microorganisms. J. Paramedical Sci. 2012;3.

16. Shaobin G, Wu Y, Li K, Ma S, Wang Q, Wang R. A Pilot study of the effect of audible sound on the growth of Escherichia coli. Colloids Surf B: Biointerfaces. 2010; 78(2):367-371.

17. Niral Sarvaiya, Vijay Kothari. Effect of audible sound in form of music on microbial growth and production of certain important metabolites. Microbiology. 2015; 84(2):227-235.

18. Ayan I, Aslan G, Cömelekoğlu U, Yilmaz $\mathrm{N}$, Colak M. The effect of low intensity pulsed sound waves delivered by the exogen device on Staphylococcus aureus morphology and genetics. (In Turkish) Acta Orthop Traumatol Turc. 2008;42(4):272277.

19. Norris V, Hyland, GJ. Do bacteria sing? Sonic intercellular communication between bacteria may reflect electromagnetic intracellular communication involving coherent collective vibrational modes that could integrate enzyme activities and gene expression. Mol Microbiol. 1997;24:879980.

20. Matsuhashi M, Pankrushina AN, Takeuchi $\mathrm{S}$, Ohshima $\mathrm{H}$, Miyoi $\mathrm{H}$, Endoh $\mathrm{K}$, et al. Production of sound waves by bacterial cells and the response of bacterial cells to sound. J Gen Appl Microbiol. 1998;44(1): 49-55. 
21. Zimmermann $U$, Fermin C. Shape deformation of the organ of Corti associated with length changes of outer hair cell. Acta Otolaryngol. 1996;116(3): 395-400.

22. Fettiplace R, Hackney CM. The sensory and motor roles of auditory hair cells. Nature Neuroscience. 2006;7(1):19-29.

Available:https://doi.org/10.1038/nrn1828

23. Chan DK, Hudspeth AJ Ca2+ currentdriven nonlinear amplification by the mammalian cochlea in vitro. Nature Neuroscience. 2005;8(2):149-155.

Available:https://doi.org/10.1038/nn1385.

24. Ashmore J. Cochlear outer hair cell motility. Physiol Rev. 2008;88(1):173210.

Available:https://doi.org/10.1152/physrev.0 0044.2006

25. Müller, $U$ Cadherins and mechanotransduction by hair cells. Curr Op Cell Biol. 2008;20(5):557-566. Available:https://doi.org/10.1016/j.ceb.200 8.06.004.

PMC: 2692626.

26. Rabbitt RD, Boyle R, Highstein SM. Mechanical amplification by hair cells in the semicircular canals. PNAS. 2010; 107(8):3864-3869.

Available:https://doi.org/10.1073/pnas.090 6765107

27. Lestard NR, Valente RC, Lopes AG, Capella MA. Direct effects of music in nonauditory cells in culture. Noise Health. 2013;15(66):307-314.

Available:https://doi.10.4103/14631741.116568

28. Lestard NR, Capella MA. Exposure to music alters cell viability and cell motility of human non auditory cells in culture. Evidence-Based Compl Alt Med; 2016. Art. ID 6849473:7 p.

Available:https://doi.org/10.1155/2016/684 9473

29. Hallam S. The power of music: a research synthesis of the impact of actively making music on the intellectual, social and personal development of children and young people iMerc: Sitra, Kingdom of Bahrain; 2015.

30. Thoma MV, La Marca R, Brönnimann R, Finkel L, Ehlert U, Ntaer UM.The effect of music on the human stress response. PLoS ONE. 2013;8(8):e70156.
Available:https://doi.org/10.1371/journal.po ne.0070156

31. Stefano GB, Zhu W, Cadet P, Salamon E, Mantione KJ. Music alters constitutively expressed opiate and cytokine processes in listeners. Med Sci Monit. 2004;10(6): 18-27.

32. Dávila SG, Campo JL, Gil MG, Prieto MT, Torres O. Effects of auditory and physical enrichment on 3 measurements of fear and stress (tonic immobility duration, heterophil to lymphocyte ratio, and fluctuating asymmetry) in several breeds of layer chicks. Poult Sci. 2011;90(11):2459-2466.

Available:https://doi.org/10.3382/ps.201101595

33. Bonzom, JM. L'asymétrie fluctuante un biomarqueur morphométrique pour évaluer la qualité de l'environnement. PhD, Univ. Sherbrook, Canada. SavoirUdeS. 1999.

Available:https://savoirs.usherbrooke.ca/ha ndle/11143/4992

34. Fukuil $\mathrm{H}$, Toyoshima AK. Music facilitates the neurogenesis, regeneration and repair of neurons. Med Hypotheses. 2008; 71(5):765-769.

Available:https://doi.org/10.1016/j.mehy.20 08.06.019

35. Kim $H$, Lee $M H$, Chang HK, Lee $\mathrm{TH}$, Lee $\mathrm{HH}$, Shin MC, et al. Influence of prenatal noise and music on the spatial memory and neurogenesis in the hippocampus of developing rats. Brain Dev. 2006;28(2):09114.

Epub 2005 Sep 21.

36. Wadhwa S, Anand $P$, Bhowmick D. Quantitative study of plasticity in the auditory nuclei of chick under conditions of prenatal sound attenuation and overstimulation with species specific and music sound stimuli. Int J Dev Neurosci. 1999;17(3):239-253.

37. Alladi PA, Roy T, Singh N, Wadhwa S. Prenatal auditory enrichment with speciesspecific calls and sitar music modulates expression of $\mathrm{Bcl}-2$ and $\mathrm{Bax}$ to alter programmed cell death in developing chick auditory nuclei. Int J Dev Neurosci. 2005; 23(4):363-373.

38. Exbrayat JM, Moudilou EN, Abrouk L, Brun C. Apoptosis in amphibian development. Advances in Bioscience and Biotechnology. 2012;2012(3):669-678. Available:https://doi.org/10.4236/abb.2012. 326087 
39. Kirste I, Nicola Z, Kronenberg G, Walker $\mathrm{TL}$, Liu RC, Kempermann G. Is silence golden? Effects of auditory stimuli and their absence on adult hippocampal neurogenesis. Brain Struct Funct. 2015; 220(2):1221-1228.

Available:https://doi.org/10.1007/s00429013-0679-3

40. Sanyal $T$, Kumar V, Nag TC, Jain $S$, Sreenivas V, Wadhwa S. Prenatal loud music and noise: differential impact on physiological arousal, hippocampal synaptogenesis and spatial behavior in one-day-old chicks. PLoS One. 2013;8(7): e67347.

Available:https://doi.org/10.1371/journal.po ne.0067347

41. Sanyal T, Palanisamy P, Nag TC, Roy TS, Wadhwa S. Effect of prenatal loud music and noise on total number of neurons and glia, neuronal nuclear area and volume of chick brainstem auditory nuclei, field $L$ and hippocampus: a stereological investigation. Int J Dev Neurosci. 2013;31(4):234244.

Available:https://doi.org/10.1016/j.ijdevneu. 2013.02.004

42. Panicker H, Wadhwa S, Roy TS. Effect of prenatal sound stimulation on mediorostral neostriatum/hyperstriatum ventral region of chick forebrain: A morphometric and immunohistochemical study. J Chem Neuroanat. 2002;24(2):127-135.

43 Lopez-Teijón M, Castelló C, Asencio M, Fernández $P$, Farreras $A$, Rovira $S$ et al., Improvement of fertilization rates of in vitro cultured human embryos by exposure to sound vibrations. Journal of Fertilization: In vitro - IVF-Worldwide, Reproductive Medicine, Gen Stem Cell Biol. 2015;3(4): 1000160.

Available:https://doi.org/10.4172/23754508.100016

44. Hasegawa $\mathrm{Y}$, Kubota $\mathrm{N}$, Inagaki $\mathrm{T}$, Shinagawa N. Music therapy induced alternations in natural killer cell count and function. (in Japanese) Nihon Ronen Igakkai Zasshi. 2001;38(2):201-204.

45. Bittman BB, Berk LS, Felten DL, Westengard J, Simonton OC, Pappas J et al. Composite effects of group drumming music therapy on modulation of neuroendocrine-immune parameters in normal subjects. Altern Ther Health Med. 2001;7(1):38-47.
46. Hirokawa $E$, Ohira $H$. The effects of music listening after a stressful task on immune functions, neuroendocrine responses, and emotional states in college students. J Music Ther. 2003;40(3):189211.

47. Wachi $M$, Koyama $M$, Utsuyama $M$, Bittman BB, Kitagawa M, Hirokawa K. Recreational music-making modulates natural killer cell activity, cytokines, and mood states in corporate employees. Med Sci Monit. 2007;13(2):CR57-70.

48. Lu SY, Peng GY, Gu LG, Li ZM, Yin SJ. Effect and mechanisms of gong-tone music on the immunological function in rats with Liver (Gan)-qi depression and Spleen (Pi)-qi deficiency syndrome in rats. Chin J Integr Med. 2013;19(3):212216.

Available:https://doi.org/10.1007/s11655011-0946-1

49. Lu $Y$, Liu M, Shi S, Jiang $H$, Yang L, Liu X et al. Effects of stress in early life on immune functions in rats with asthma and the effects of music therapy. J Asthma. 2010;47(5):526-531.

Available:https://doi.org/10.3109/02770901 003801964

50. Nuñez MJ, Maña $P$, Liñares $D$, Riveiro MP, Balboa J, Suarez-Quintanilla J et al. Music, immunity and cancer. Life Sci. 2002;71(9): 1047-1057.

51. Liao P. Mozart may prevent heart transplant rejection: discovery wins Harvard University's Ig Nobel 2013 prize in medicine. Nat Med J India. 2013;26(6): 381.

52. Uchiyama $M$, Jin $X$, Zhang $Q$, Amano $A$, Bashuda H, Niimi N. Auditory stimulation of opera music induced prolongation of murine cardiac allograft survival and maintained generation of regulatory CD4+CD25+ cells. J Cardiothor Surg. 2012;7(1):26.

53. Uchiyama $\mathrm{M}$, Jin $\mathrm{X}$, Zhang $\mathrm{Q}$, Amano A, Watanabe T. Niimi M. Music exposure induced prolongation of cardiac allograft survival and generated regulatory $\mathrm{CD}^{+}$ cells in mice. Transplant Proc. 2012;44 (4):1076-1079.

Available:https://doi.org/10.1016/j.transpro ceed.2012.02.008

54. Erken G, Bor Kucukatay M, Erken HA, Kursunluoglu R, Genc $O$. Influence of classical and rock music on red blood cell 
rheological properties in rats. Med Sci Monit. 2008;14(1):BR 28-33.

55. Albanese A, Battisti E, Vannoni D, Acetoi E, Galassi G, Giglioni S, Tommassini V, Giordano N. Alterations in adenylate kinase activity in human PBMCs after in vitro exposure to electromagnetic field: comparison between extremely low frequency electromagnetic field (ELF) and therapeutic application of a musically modulated electromagnetic field (TAMMEF). J Biomed. Biotechnol. 2009; 717941.

Available:https://doi.org/10.1155/2009/717 941

56. Corallo C, Volpi N, Franci D, Vannoni D, Leoncini R, Landi G, Guarna M, Montella A, Albanese A, Battisti E, Fioravanti A, Nuti $\mathrm{R}$, Giordano N. Human osteoarthritic chondrocytes exposed to extremely lowfrequency electromagnetic fields (ELF) and therapeutic application of musically modulated electromagnetic fields (TAMMEF) systems: A comparative study. Rheumatol Int. 2013;33(6):15671575.

Available:https://doi.org/10.1007/s00296012-2600-4

57. Corallo C, Battisti E, Albanese A, Vannoni D, Leoncini R, Landi G, Gagliardi A, Landi C, Carta S, Nuti R, Giordano N. Proteomics of human primary osteoarthritic chondrocytes exposed to extremely lowfrequency electromagnetic fields (ELF EMFs) and to therapeutic application of musically modulated electromagnetic fields (TAMMEF). Electromagn Biol Med. 2014; 33 (1):3-10.

Available:https://doi.org/10.3109/15368378 .2013.782316

58. Vannoni D, Albanese A, Battisti E, Aceto E, Giglioni S, Corallo C, Carta S, Ferrata P, Fioravanti A, Giordano N.2012. In vitro exposure of human osteoarthritic chondrocytes to ELF fields and new therapeutic application of musically modulated electromagnetic fields: biological evidence. J Biol Regul Homeost Agents. 2012;26(1):39-49.

59. Clark WW. Noise exposure from leisure activities: A review. J Acoust Soc Am. 1991;90(1):175-181.

60. Aydin MU, Ungoren MK, Aydin N, Halici Z, Onder A, Gundogdu C, Izci Y. The effects of impulse noise on the epithelial cells of the choroid plexus. Turk Neurosurg. 2011; 21(2):191-196.

61. McCarthy DO, Ouimet ME, Daun JM. The effects of noise stress on leukocyte function in rats. Res Nurs Health. 1992; 15(2):131-137.

62. Nelson A, Hartl W, Jauch KW, Fricchione $\mathrm{GL}$, Benson $\mathrm{H}$, Warshaw AL, Conrad C. The impact of music on hypermetabolism in critical illness. Curr Opin Clin Nutr Metab Care. 2008;11(6):790-794.

Available:https://doi.org/10.1097/MCO.0b0 13e328314dd01

63. Rauscher FH, Shaw GL, Ky CN. Music and spatial task performance. Nature. 1993; 365(6447):611.

64. Pauwels EK, Volterrani D, Mariani G, Kostkiewics M. Mozart, music and medicine. Med Princ Pract. 2014;23(5): 403-412.

Available:https://doi.org/10.1159/00036487 3

65. Russo C, Russo A, Gulino R, Pellitteri R, Stanzani S. Effects of different musical frequencies on NPY and Ghrelin secretion in the rat hypothalamus. Brain Res Bull. 2017;132:204-212.

Available:https://doi.org/10.1016/j.brainres bull.2017.06.002

66. Nakamura T, Tanida M, Niijima A, Hibino $H$, Shen J, Nagai K. Auditory stimulation affects renal sympathetic nerve activity and blood pressure in rats. Neurosci Lett. 2007;416(2):107-12.

67. Nakamura T, Tanida M, Niijima A, Nagai K. Effect of auditory stimulation on parasympathetic nerve activity in urethaneanesthetized rats. In vivo. 2009;23(3):415419.

68. Oikkonen J, Onkamo P, Järvelä I, Kanduri C. Convergent evidence for the molecular basis of musical traits. Sci Rep. 2016; 6:39707.

Available:https://doi.org/10.1038/srep3970 7

69. Fukui H, Toyoshima K. Music increase altruism through regulating the secretion of steroid hormones and peptides. Med Hypotheses. 2014;83(6):706-708.

Available:https://doi.org/10.1016/j.mehy.20 14.09.023

70. Dóro CA, Neto JZ, Cunha R, Dóro MP. Music therapy improves the mood of patients undergoing hematopoietic 
stem cells transplantation (controlled randomized study). Support Care Cancer. 2017;25(3):1013-1018.

Available:https://doi.org/10.1007/s00520016-3529-z
71. Gao J, Chen S, Lin S, Han H. Effect of music therapy on pain behaviors in rats with bone cancer pain. J BUON. 2016; 21(2):466-472.

(c) 2019 Exbrayat and Brun; This is an Open Access article distributed under the terms of the Creative Commons Attribution License (http://creativecommons.org/licenses/by/4.0), which permits unrestricted use, distribution, and reproduction in any medium, provided the original work is properly cited.

Peer-review history:

The peer review history for this paper can be accessed here: http://www.sdiarticle3.com/review-history/49598 